\title{
Od kreślenia planów miejscowych do cyfrowego modelowania miast. Dziesięć lat Koła Naukowego Gospodarki Przestrzennej
}

\section{Katarzyna Goch, Sebastian Maciulewski}

\begin{abstract}
STRESZCZENIE
Celem niniejszego artykułu jest przedstawienie historii dziesięcioletniej działalności Koła Naukowego Gospodarki Przestrzennej (KNGP) oraz zorganizowanej w ramach obchodów jubileuszowej rocznicy ogólnopolskiej konferencji naukowej „10 wyzwań gospodarki przestrzennej”. Koło Naukowe Gospodarki Przestrzennej powstało w 2007 r. przy Wydziale Geodezji i Kartografii Politechniki Warszawskiej. Zrzesza ono studentów i absolwentów kierunku Gospodarka Przestrzenna na Politechnice Warszawskiej. Celem działalności Koła jest rozwój zainteresowań studentów związanych z gospodarką przestrzenną oraz upowszechnianie wiedzy dotyczącej powyższych zagadnień. Głównym obszarem zainteresowania Koła są zagadnienia związane z zagospodarowaniem i kształtowaniem przestrzeni, jak również dotyczące zrównoważonego rozwoju lokalnego i regionalnego, kwestii środowiska przyrodniczego, rozwoju społeczno-gospodarczego oraz zagadnienia związane z projektowaniem urbanistycznym. Na przestrzeni lat Koło podjęło się stworzenia kilku projektów, swoją tematyką łączących urbanistykę, środowisko, a także systemy informacji przestrzennej. W latach 2008-2016 Koło było beneficjentem 8 grantów rektorskich oraz realizowało, również we współpracy z innymi organizacjami studenckimi z innych uczelni, wiele konferencji i warsztatów.

W maju 2017 r., w ramach obchodów dziesięciolecia działalności Koła Naukowego Gospodarki Przestrzennej, miała miejsce ogólnopolska konferencja naukowa „10 wyzwań gospodarki przestrzennej”. W konferencji wzięli udział eksperci z dziedziny planowania przestrzennego, odnosząc się do aspektów związanych z demografia, odpornością miast, transportem, reprywatyzacja, ochroną krajobrazu oraz ochroną środowiska przyrodniczego. Rezultaty swoich prac przedstawili również członkowie Koła Naukowego. Wnioski ze spotkania świadczą o potrzebie wymiany doświadczeń pomiędzy profesjonalistami z różnych dziedzin, oraz pomiędzy światem akademickim a praktykami planowania przestrzennego.
\end{abstract}

\section{Historia działalności Koła Naukowego}

Koło Naukowe Gospodarki Przestrzennej (KNGP) powstało w 2007 r. przy Wydziale Geodezji i Kartografii Politechniki Warszawskiej. Zrzesza ono studentów i absolwentów kierunku Gospodarka Przestrzenna na Politechnice Warszawskiej. Celem działalności Koła jest rozwój i pogłębianie zainteresowań studentów związanych z gospodarką przestrzenną oraz poszerzanie, promowanie i upowszechnianie wiedzy dotyczącej powyższych zagadnień. Głównym obszarem zainteresowania Koła są zagadnienia związane z zagospodarowaniem i kształtowaniem przestrzeni, jak również dotyczące zrównoważonego rozwoju lokalnego i regionalnego, kwestii środowiska przyrodniczego, rozwoju społeczno-gospodarczego oraz zagadnienia związane z projektowaniem urbanistycznym. 


\section{Granty badawcze i projekty naukowe}

Od momentu powstania, Koło Naukowe Gospodarki Przestrzennej było beneficjentem 8 grantów rektorskich. Szeroka tematyka podjętych prac badawczych obejmowała aspekty związane m.in. z zagospodarowaniem przestrzeni, rozwojem gmin, systemem nawietrzania miasta, zjawiskiem suburbanizacji miast, energetyką odnawialną oraz stanem zdrowia ludności miejskiej. Granty badawcze z lat 2008 i 2009 dotyczyły zagospodarowania przestrzennego okolic jeziora Łąkie w gminie Skępe. Studenci zaangażowani w te projekty badali stan środowiska przyrodniczego i powstałe zagrożenia, mając na celu określenie głównych kierunków wykorzystania gruntów i funkcji dla omawianego obszaru. Rezultatem prac było opracowanie zawierające główne źródła zanieczyszczeń jeziora Łąkie, ocenę wpływu na środowisko terenów rekreacyjnych, zlokalizowanie obszarów problemowych oraz analizę możliwego rozwoju gminy. Grant rektorski „Opracowanie założeń do projektu kształtowania krajobrazu oraz strategii rozwoju dla gminy Dębe Wielkie" z 2010 r. dotyczył zbadania wpływu budowy drogi szybkiego ruchu - w tym przypadku autostrady A2 - na tereny rolnicze, znajdujące się w zasięgu oddziaływania dużej aglomeracji. W szczególności analizowany był wpływ inwestycji na społeczność lokalna, środowisko przyrodnicze oraz powiązania przestrzenne, a także jej potencjalne pozytywne lub negatywne konsekwencje. Rezultaty badania zawierały wyniki analizy szans i zagrożeń płynących z budowy autostrady oraz perspektywę rozwoju gminy po zakończeniu inwestycji. Prace przeprowadzone w 2011 r. w ramach grantu „Analiza uwarunkowań, stanu i możliwości zagospodarowania terenu Zakrzówka” zaowocowały przeprowadzeniem analiz uwarunkowań przyrodniczych oraz atrakcyjności inwestycyjnej Zakrzówka, a także stworzeniem planszy z koncepcją zagospodarowania terenu objętego badaniem. Odmienne aspekty zagospodarowania przestrzennego zostały poruszone $\mathrm{w}$ grancie rektorskim w 2012 r. Grant „Analiza urbanistyczno-środowiskowa fragmentu Mokotowskiego Klina Nawietrzającego" miał na celu zbadanie wpływu zabudowy terenów Korytarza Mokotowskiego na system nawietrzania Warszawy. Projekt obejmował analizy planistyczne i środowiskowe, uwzględniające powiązania komunikacyjne i funkcjonalne terenów klina z pozostałą częścią miasta. W dalszej części projektu, przy wykorzystaniu specjalistycznego oprogramowania, zostały przeprowadzone analizy przepływu powietrza, analizy zacienienia oraz rozkładu temperatur w klinie, a w rezultacie analiza wpływu nowo wybudowanych osiedli na funkcjonowanie systemu nawietrzania Warszawy. Grant badawczy pozwolił zaangażowanym studentom zapoznać się z funkcjonowaniem systemu wymiany powietrza w mieście, metodami ochrony tych obszarów, jak również wykorzystywania w praktyce specjalistycznego oprogramowania projektowego. Kolejny grant badawczy realizowany przez Koło Naukowe Gospodarki Przestrzennej dotyczył zjawiska nadmiernego rozlewania się miast. Efektem badania „Analiza zjawiska niekontrolowanego rozprzestrzeniania się miast na przykładzie warszawskiej dzielnicy Białołęka" były wieloetapowe analizy na poziomie miasta, dzielnicy i osiedla poświęcone suburbanizacji wybranego terenu. W wyniku badań zostały zidentyfikowane negatywne zjawiska oraz powstał projekt miejscowego 
planu zagospodarowania przestrzennego wybranego fragmentu dzielnicy Białołęka m.st. Warszawy, prezentujący propozycję prawidłowego zagospodarowania analizowanego obszaru. W 2014 r. Koło Naukowe Gospodarki Przestrzennej wraz z Kołem Naukowym Geodezji i Kartografii oraz ze Studenckim Kołem Naukowym Energetyki Niekonwencjonalnej brało udział w projekcie zespołowym „Technologiczne i przestrzenne aspekty lokalizacji inwestycji fotowoltaicznych”, którego celem było zlokalizowanienajkorzystniejszych terenów pod farmy fotowoltaiczne. Zadaniem KNGP było opracowanie metodyki wyznaczania potencjalnych lokalizacji inwestycji fotowoltaicznych z zastosowaniem technologii GIS (Geographic Information System). Ostatnim, ósmym w historii działalności Koła Naukowego grantem rektorskim był projekt: „Określenie czynników środowiskowych i urbanistycznych wpływających na stan zdrowia mieszkańców miasta st. Warszawy”. Celem badania było zbadanie czynników środowiskowych i urbanistycznych oraz określenie ich wpływu na stan zdrowia mieszkańców Warszawy oraz identyfikacja czynników decydujących o zdrowiu i samopoczuciu mieszkańców miasta. W prace nad projektem zaangażowani byli członkowie od najmłodszych lat studiów. Jako rezultat projektu powstał ranking dzielnic najlepszych dla zdrowia oraz wytyczne rozwoju dla miasta, mające na celu poprawę jakości życia jego mieszkańców. Współpraca z Kołem Naukowym Informatyków, działającym przy Wydziale Matematyki i Nauk Informacyjnych Politechniki Warszawskiej pozwoliła na wizualizację rezultatów prac w postaci aplikacji mobilnej obrazującej stan środowiska wybranych dzielnic.

Uwzględniając wnioski z przeprowadzonych w ostatnich latach prac badawczych nad związkiem pomiędzy stanem środowiska przyrodniczego a jakością życia w terenach zurbanizowanych, członkowie Koła Naukowego postanowili ukierunkować swoje

\section{Ryc. 1. Korytarze przepływu wiatru w kierunku NW-SE i W-E}
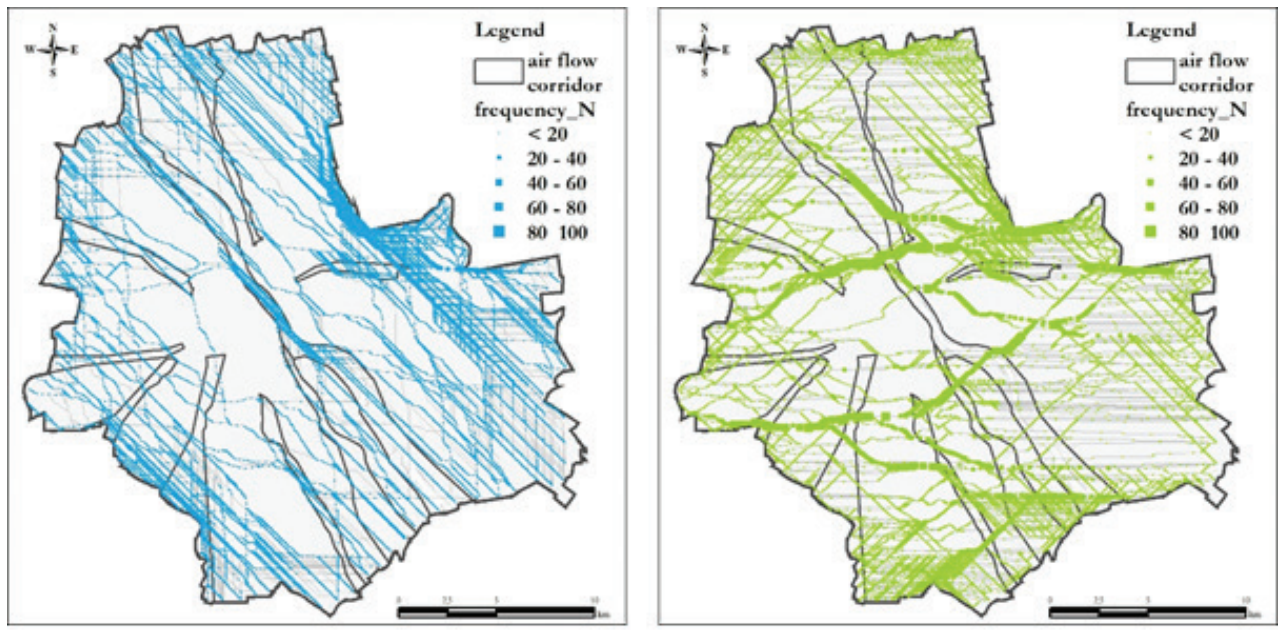

Źródło: K. Goch i in. 2017 


\section{Ryc. 2. Wizja terenowa wraz z Fundacją „Dobra Wola” na terenie pod ośrodek dla osób niepełnosprawnych}

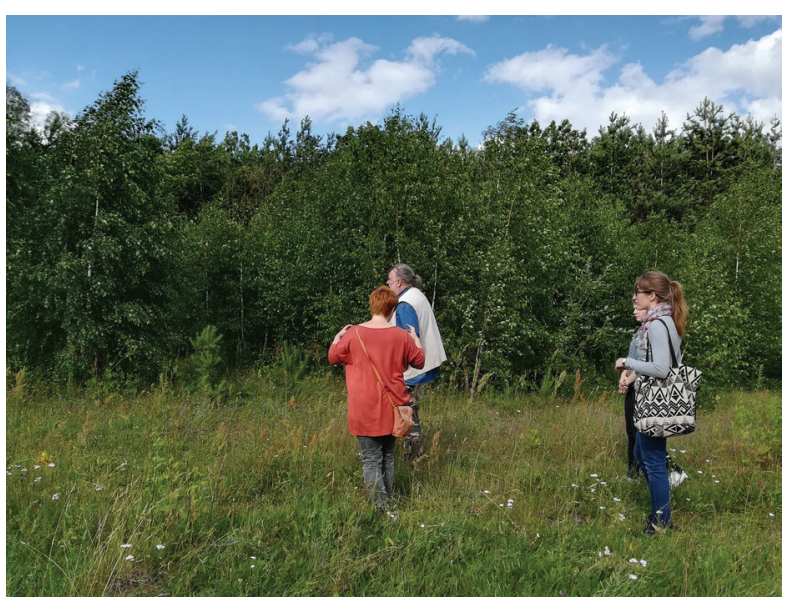

zainteresowania naukowe na zapewnienie należytej jakości powietrza $\mathrm{w}$ mieście, będące - co potwierdziło występujące ostatnio w Warszawie zjawisko smogu wyzwaniem dla dużych miast. Gęsta i wysoka zabudowa, wysokie natężenie ruchu drogowego, niekorzystne położenie lub warunki meteorologiczne mają znaczny wpływ na występowanie zanieczyszczeń atmosferycznych. Celem aktualnie trwającego projektu „Ocena wpływu rozwoju zabudowy w latach 1992-2016 na stopień przewietrzania m.st. Warszawy" jest analiza zmian zachodzących w morfologii Warszawy w ostatnich kilkunastu latach oraz związanych z nimi zmian we właściwościach aerodynamicznych terenu. Analiza szorstkości terenu pozwala zidentyfikować rzeczywisty przebieg korytarzy nawietrzających (ryc. 1) i na tej podstawie sformułować zalecenia dotyczące ochrony terenów obejmujących system wymiany i regeneracji powietrza przed pozbawieniem ich swojej funkcji. Kolejnym etapem badania jest konfrontacja wyników modelowania z rzeczywistościa, poprzez pomiary terenowe prędkości i kierunku wiania wiatru w kilkudniowych kampaniach pomiarowych.

Koło Naukowego Gospodarki Przestrzennej łączy osoby nie tylko o zainteresowaniach przyrodniczych, ale również studentów odnajdujących się w projektach urbanistycznych i architektonicznych. Celem najnowszego projektu Koła Naukowego jest zaprojektowanie „Farmy Dobrej Woli” - kompleksu mieszkalno-usługowego dla dorosłych osób niepełnosprawnych umysłowo lub fizycznie (ryc. 2). Na zaplanowanej działce mają znaleźć się domy mieszkalne, budynki gospodarcze, obiekt służby zdrowia, sala konferencja oraz tereny rekreacyjne. Całość ma uwzględniać innowacyjne rozwiązania stosowane w budynkach inteligentnych, które będą ułatwiać życie mieszkańcom obiektu, co czyni ten projekt wyjątkowym i nowatorskim w swoim zakresie [Grela 2017].

\section{Działalność dydaktyczna}

Działalność Koła Naukowego Gospodarki Przestrzennej opiera się nie tylko na grantach rektorskich. Jedną z pozostałych aktywności są warsztaty urbanistyczne, adresowane do osób zainteresowanych tematyką urbanistyki i gospodarki przestrzennej, będących zarówno studentami Politechniki Warszawskiej, jak i innych szkół wyższych z całej Polski. W ciągu ośmiu lat swojego istnienia Koło Naukowe zorganizowało trzy takie wydarzenia w ramach 
cyklu „Akcja - Kreacja”. Celem pierwszego z nich było zwrócenie uwagi na problemy, z którymi borykają się śródmieścia miast Polski i świata. Zaproszeni goście oraz studenci przez 4 dni rozpatrywali kwestie takie jak: chaos komunikacyjny, natłok reklam, brak przestrzeni publicznych czy klimat miasta. Celem drugich warsztatów na temat "Jasne granice - czytelne ulice" było uporządkowanie obecnie niewyraźnie przebiegających granic ulic w osiedlowych częściach miast na przykładzie dzielnicy Bemowo m. st. Warszawy. Ostatnie warsztaty, realizowane w trakcie obchodów jubileuszu Koła Naukowego, dotyczyły rewitalizacji warszawskiej Starej Pragi. Uczestnicy mieli za zadanie w ciągu dwóch dni opracować koncepcję modernizacji wybranego kwartału zabudowy oraz obronić swoją ideę $\mathrm{w}$ trakcie prezentacji przed komisją oceniającą.

Działalność Koła Naukowego polega również na udziale w różnych konferencjach. Członkowie Koła na przestrzeni lat odbyli niejedną podróż do miast w Polsce i za granica, aby dzielić się efektami swoich prac z innymi pasjonatami gospodarki przestrzennej. Poza uczestniczeniem w konferencjach, Koło Naukowe bierze również udział w ich organizowaniu. Najlepszym tego przykładem jest GISDAY - coroczne święto geografii i systemów informacji przestrzennej, które organizowane jest we współpracy z wieloma organizacjami studenckimi z warszawskich uczelni. W 2015 r. Koło Naukowe Gospodarki Przestrzennej przewodniczyło organizacji tej konferencji, która gościła w progach Politechniki Warszawskiej. KNGP dało się też poznać jako organizator wielu gier miejskich, odbywających się na terenie Warszawy, organizując m.in. grę na warszawskim Mariensztacie w ramach GISDAY 2014 i gry miejskiej na terenie ogrodów Pałacu w Wilanowie. Poza tym członkowie Koła aktywnie uczestniczą w życiu Uczelni, organizując szkolenia dla członków Koła, włączając się w akcję Drzwi Otwartych dla przyszłych studentów, a także innych wydarzeń odbywających się na Wydziale Geodezji i Kartografii. W dobie internetu Koło Naukowe istnieje zarówno w świecie rzeczywistym, jak i wirtualnym, posiadając własne konto w serwisie Facebook, służące do informowania sympatyków m.in. o zbliżających się wydarzeniach. Koło Naukowe ma również regularnie aktualizowaną stronę internetową którą znaleźć można pod adresem: www.kngp.gik.pw.edu.pl.

\section{Konferencja naukowa „10 wyzwań gospodarki przestrzennej”}

Koło Naukowego Gospodarki Przestrzennej w ramach obchodów jubileuszu dziesięciolecia swojej działalności zorganizowało konferencję poświęconą wymianie doświadczeń ekspertów z zakresu teorii i praktyki związanej z planowaniem przestrzennym i zarządzaniem terytorialnym. Ogólnopolska konferencja „10 wyzwań gospodarki przestrzennej” odbyła się 19 maja 2017 r., w Gmachu Głównym Politechniki Warszawskiej.

Na uroczystości towarzyszące obchodom dziesięciolecia Koła Naukowego składała się również seria wydarzeń w drugiej połowie maja 2017 r. Rozpoczęło je spotkanie członków i absolwentów Koła, podczas którego założyciele stowarzyszenia mogli spotkać obecnych studentów i skonfrontować swoje wspomnienia z pierwszych kroków działalności naukowej z obecnymi aktywnościami. Pełny przegląd tych działań został zaprezentowany na kilku- 
Ryc. 3. Sesja posterowa prezentująca dorobek naukowy członków KNGP

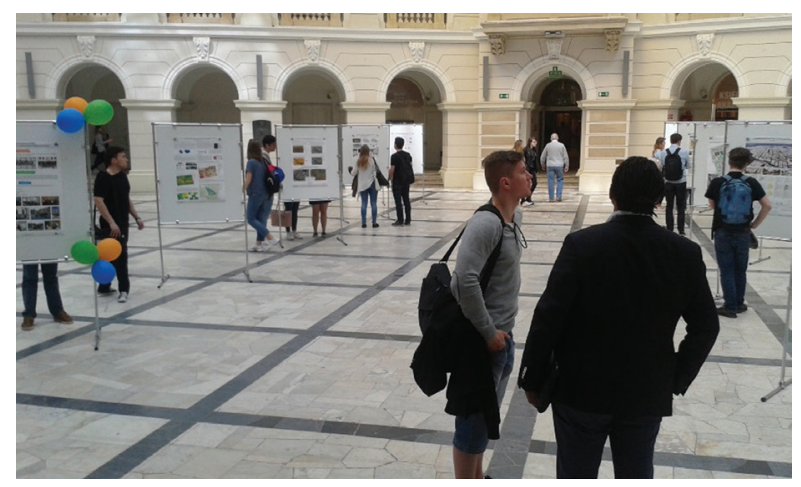

dniowej sesji plakatowej w Auli Głównej Politechniki Warszawskiej (ryc. 3). Zostało pokazanych 20 prac Koła Naukowego, obejmujących zarówno wyniki grantów naukowych, jak i indywidualnych projektów członków. Miały również miejsce warsztaty urbanistyczne „Akcja - Kreacja”, corocznie organizowane przez Koło dla uczestników z całej Polski. Celem warsztatów jest zapoznanie uczestników z metodami projektowania urbanistycznego poprzez wspólną inwentaryzację w terenie oraz dwudniowe warsztaty, w trakcie których grupy projektowe mają za zadanie przygotować swoją koncepcję terenu oraz zaprezentować ją przed pozostałymi uczestnikami oraz komisją oceniająca, w skład której wchodzi kadra akademicka Wydziału Geodezji i Kartografii Politechniki Warszawskiej. Warsztaty cieszą się corocznie niezmiennym zainteresowaniem. Tegoroczna, jubileuszowa edycja nosiła tytuł „Akcja - Modernizacja” i dotyczyła niezwykle atrakcyjnego tematu modernizacji osiedla na Starej Pradze (ryc. 4).

Ryc. 4. Warsztaty urbanistyczne „Akcja - Modernizacja”

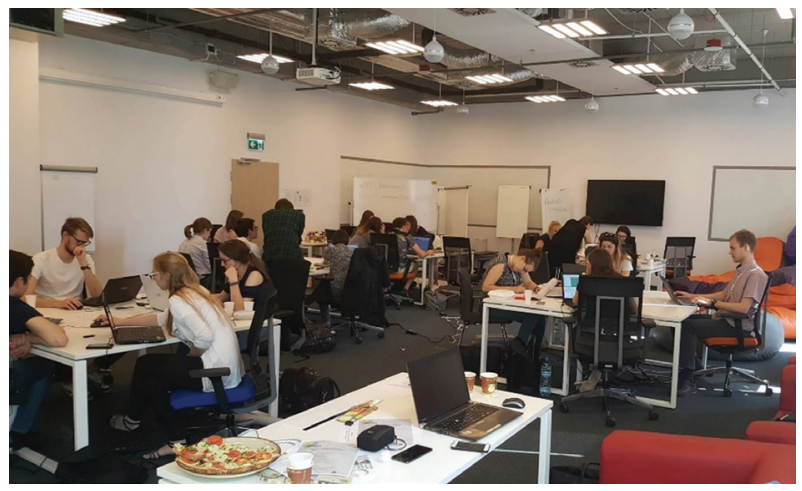

Podstawą konferencji „10 wyzwań gospodarki przestrzennej" było założenie o interdyscyplinarnym charakterze omawianej dziedziny, zatem zaproszeni prelegenci reprezentowali wiele środowisk z dziedzin planistyki, urbanistyki, ochrony środowiska oraz nauk społeczno-gospodarczych, w tym również środowiska akademickiego i studenckiego. Konferencja składała się z czterech sesji tematycznych, odnoszących się do określonych aspektów gospodarowania przestrzenią: zarządzania aglomeracją miejską kształtowania krajobrazu miast, ochrony środowiska na terenach zurbanizowanych oraz działalności studenckiej. Wydarzenie moderował absolwent Kierunku Gospodarka Przestrzenna na Politechnice Warszawskiej oraz członek Koła Naukowego Gospodarki Przestrzennej - Sebastian Maciulewski. 
Konferencję otworzyła Dziekan Wydziału Geodezji i Kartografii, prof. dr hab. Alina Maciejewska, która w swoim wystąpieniu podziękowała licznie zgromadzonym gościom oraz zaznaczyła, jak ważna jest aktywność studencka wykraczająca poza ramy ściśle określone programem nauczania. Gościem specjalnym wydarzenia, był prof. Harald Kegler z Uniwersytetu w Kassel, który w wystąpieniu rozpoczynającym imprezę odniósł się do zagrożeń, jakie niesie za sobą epoka antropocenu. W czasach intensywnego przekształcania krajobrazu przez działalność człowieka miasta powinny prężenie odpowiadać na nowe zjawiska (koncepcja resilient cities). Prof. Kegler, jako jedno z przykładowych narzędzi rewitalizacji terenów poprzemysłowych przytoczył pokazowy projekt modernizacji Zagłębia Ruhry „IBA Emscherpark”, obejmujący szeroko zakrojone działania mające na celu przeobrażenie regionu. Otwarcie konferencji zakończyło wystąpienie Prezes Koła Naukowego Gospodarki Przestrzennej Katarzyny Goch, która podziękowała prelegentom i gościom za chęć udziału w wydarzeniu i pokrótce opisała działalność naukową i dydaktyczną stowarzyszenia z ostatniej dekady.

Sesję „Wyzwania w zarządzaniu aglomeracją miejską" rozpoczął dr hab. Przemysław Śleszyński z Instytutu Geografii i Przestrzennego Zagospodarowania im. S. Leszczyckiego PAN. W swoim wystąpieniu poruszył związek pomiędzy rozprzestrzenianiem się miast a prognozą demograficzna, która jednoznacznie wskazuje na zmniejszanie się liczby ludności w Polsce. W kontraście do tych danych P. Śleszyński zaprezentował opracowanie pokazujące przeszacowanie dokumentów planistycznych: plany miejscowe w skali kraju zapewniają tereny pod zabudowę dla ok. $58 \mathrm{mln}$ ludzi, zaś studia uwarunkowań i kierunków zagospodarowania terenu dla 117-143 mln mieszkańców, co stanowi aż czterokrotność aktualnej ich liczby. Kolejny prelegent, Pan Jan Śpiewak, Radny dzielnicy Śródmieście m. st. Warszawy, zaprezentował procedury i nieprawidłowości, jakie miały miejsce $\mathrm{w}$ procesie reprywatyzacji nieruchomości w Warszawie. Nośny temat wystąpienia, zaangażowanie prelegenta oraz przytoczone dane o nadużyciach $\mathrm{w}$ trakcie całego procesu przyciągnęły uwagę słuchaczy. Sesję związaną z zarządzaniem aglomeracją zakończyło wystąpienie Pana Leszka Cisło z nowej jednostki miasta - Biura Polityki Mobilności i Transportu m. st. Warszawy. Prezentacja „Polityka parkingowa Warszawy” odnosiła się nie tylko do narzędzi, jakimi posługuje się Urząd przy regulowaniu kwestii parkingowej, ale również do wyzwań z tym związanych oraz przyszłych celów Warszawy, która podejmuje kroki w stronę tworzenia przestrzeni bardziej przyjaznych pieszym.

Druga sesja konferencji dotyczyła wyzwań w kształtowaniu krajobrazu miasta. Rozpoczął ją swoją prelekcją dr inż. Wojciech Bartoszczuk z Wydziału Geodezji i Kartografii Politechniki Warszawskiej oraz konsultant Koła Naukowego Gospodarki Przestrzennej. Prezentacja „Dziedzictwo warszawskich miast-ogrodów. Wiek zmian” odnosiła się do prób realizacji dwudziestowiecznej koncepcji idealnego miasta Ebenezera Howarda w Warszawie na przykładach miasta-ogrodu Młociny, osiedla Boernerowo - osiedla Łączności, miastaogrodu Jelonek (części północnej i części południowej), miasta-ogrodu Stare Włochy lub części zachodniej i wschodniej miasta-ogrodu Nowe Włochy. Prezentacja pokazywała szczegółowe zmiany przestrzenne i strukturalne w tych częściach Warszawy, z uwzględnieniem zmian 
kształtu działek, powierzchni i wysokości zabudowy. Kolejna prezentacja odnosiła się do niekiedy pomijanej w debatach o miastach roli sztuki w przestrzeni publicznej. Pan Radosław Gajda, współtwórca popularnej strony "Architecture is a good idea”, na przykładzie ikonicznych dzieł z całego świata zaprezentował funkcje sztuki, jako równorzędnego elementu kompozycji urbanistycznej lub formy jej uzupełnienia. Zarysował wyzwania stojące przed Warszawą - miasta wciąż niosącego ślady zniszczeń wojennych i odniósł się do przykładów odbudowy miast niemieckich. Prezentacja pociągnęła za sobą gorącą dyskusję o implementacji przykładów zagranicznych w rodzimym środowisku. Ostatni w tej sesji prelegent, Pan Michał Krasucki, Stołeczny Konserwator Zabytków, swoje wystąpienie poprowadził z użyciem wirtualnej mapy Warszawy, na której wskazywał obszary problemowe z punktu widzenia ochrony konserwatorskiej oraz przedstawił wyzwania, głównie natury prawnej i administracyjnej, stojące na przeszkodzie zabezpieczenia dziedzictwa historycznego i kulturowego Warszawy.

Kolejną sesję „Wyzwania w ochronie środowiska w mieście” rozpoczął Pan Krzysztof Skotak z Instytutu Ochrony Środowiska - Państwowego Instytutu Badawczego. Odniósł się do problemów związanych z jakością powietrza - kwestii równie aktualnych w Warszawie, co omawiana w poprzedniej sesji reprywatyzacja mieszkań. Prelegent przedstawił niepokojące dane: zarówno w kwestii całkowitej emisji pyłów PM2.5, jak i poziomów stężeń Polska znajduje się w czołówce państw europejskich. Chociaż w skali kraju za emisję zanieczyszczeń $\mathrm{w}$ Polsce $\mathrm{w}$ największej części odpowiadają procesy spalania poza przemysłem ( $\mathrm{w}$ tym głównie niska emisja, czyli indywidualne instalacje przydomowe), tak w skali Warszawy kluczowe znaczenie odgrywa transport. Wnioski z wystąpienia wyraźnie wskazywały, że jego zrównoważenie, czyli upłynnienie oraz modernizacja, powinno być jednym z głównych zadań włodarzy. Kolejnym prelegentem w sesji była dr hab. Barbara Szulczewska ze Szkoły Głównej Gospodarstwa Wiejskiego. W wystąpieniu „Zielona infrastruktura jako element struktury przestrzennej miast” wskazała, że „zielone” koncepcje urbanistyczne istnieją w naszej kulturze już od początku XX w. oraz, że znaczenie ekologicznej infrastruktury jest równie ważne dla społeczności miejskiej jak infrastruktura techniczna. Zaznaczyła, że miejscowe plany zagospodarowania przestrzennego są skuteczną metodą wdrażania zielonej infrastruktury w Warszawie. Odnosząc się do przeprowadzonej analizy [Szulczewska 2016] wskazała ogrody na dachach, zbiorniki retencyjne oraz nawierzchnie przepuszczalne, jako najbardziej popularne środki wprowadzane w dokumentach planistycznych. Ostatnim wystąpieniem w sesji było podsumowanie działalności Koła Naukowego w kontekście badań nad środowiskiem przyrodniczym przez dr. Józefa Dobiję z Wydziału Geodezji i Kartografii Politechniki Warszawskiej, konsultanta Koła Naukowego Gospodarki Przestrzennej, ze szczególnym zaznaczeniem zrealizowanego grantu rektorskiego z 2015 r., dotyczącego wpływu czynników przyrodniczych i antropogenicznych na stan zdrowia ludności miejskiej.

Ostatnia sesja konferencji poświęcona była prezentacji prac badawczych członków Koła Naukowego Gospodarki Przestrzennej. Rozpoczął ją Jan Cholewiński, prezentując problematykę tworzenia Gminnych Programów Rewitalizacji dla małych gmin na przykładzie GPR miasta Brok, za który autor wraz z zespołem zdobył nagrodę publiczności 
w ogólnopolskim konkursie „Miasto w Twoich rękach”, organizowanym w Szkole Głównej Gospodarstwa Wiejskiego w Warszawie. Następnie Dominika Grylak zaprezentowała pierwsze międzypokoleniowe warsztaty urbanistyczne „Seniorzy i studenci - razem możemy więcej”, które za swój innowacyjny charakter zostały wpisane przez Rzecznika Praw Obywatelskich do Złotej Księgi Dobrych Praktyk na Rzecz Społecznego Uczestnictwa Osób Starszych [RPO 2017]. W kolejnym wystąpieniu Zofia Przetakiewicz przedstawiła analizę obowiązujących ustaw w zakresie zagrożenia powodziowego oraz ich zastosowania w procesie planowania przestrzennego. Tę sesję, a tym samym i całą konferencję, zakończyło wystąpienie prezes Koła Naukowego Gospodarki Przestrzennej Katarzyny Goch, która zaprezentowała wyniki modelowania przepływu powietrza w Warszawie w kontekście uwzględnionych w strategicznych dokumentach miasta korytarzach nawietrzających oraz wielokrotnie poruszanych $\mathrm{w}$ trakcie wystąpień problemów z jakością powietrza w mieście.

\section{Wnioski na dziesięciolecie}

Koło Naukowe Gospodarki Przestrzennej prowadzi zróżnicowaną działalność, która ma na celu rozpowszechnianie wiedzy o gospodarowaniu przestrzenią oraz jej racjonalnym zarządzaniu. Poprzez różne akcje staramy się uwrażliwiać, poczynając od najmłodszych, na problemy związane z kształtowaniem otaczającej nas rzeczywistości oraz szukać dla nich właściwych rozwiązań. Szkolenia, konferencje i wyjazdy badawcze dają nam nie tylko nowe umiejętności, ale również możliwość poznawania nowych osób, dzielących nasze pasje i konsultowania naszych poglądów. Dzięki temu działalność w Kole Naukowym daje nie tylko wiedzę, ale również nowe spojrzenie i nowe horyzonty myślenia. W ciągu ostatnich dziesięciu lat zmieniło się nasze podejście do tematyki planowania przestrzennego. Coraz większą rolę odgrywają rozwijające się nowe technologie - serwisy społecznościowe, aplikacje mobilne, platformy do geopartycypacji. Zmieniła się również świadomość społeczności studenckiej, co widać $\mathrm{w}$ otwartości na zagraniczne doświadczenia oraz porównywanie swoich dokonań na arenie międzynarodowej, jak również w podejmowaniu wyzwań na styku dziedzin naukowych i technologicznych. Zorganizowana z okazji dziesięciolecia konferencja „10 wyzwań gospodarki przestrzennej” pozwoliła połączyć i skonfrontować punkt widzenia świata akademickiego, planistów praktyków oraz aktywistów miejskich i organizacji pozarządowych. To cenne doświadczenie pozwoliło dostrzec, że każde z tych środowisk stara się różnymi drogami dojść do tego samego celu, jakim jest racjonalne wykorzystanie otaczającej nas przestrzeni, z poszanowaniem dziedzictwa przyrodniczego i kulturowego, i że każde z nich spotyka na swojej drodze bariery, charakterystyczne dla swojej profesji i nierzadko wywołujące znamienne w skutkach konflikty. Działania na styku różnych dziedzin i zapobieganie tym konfliktom są zatem wyzwaniem, a także obowiązkiem planistów, w tym członków naszego Koła, którzy mają do odegrania znaczącą rolę w kształtowaniu przyszłej rzeczywistości. 
116 OD KREŚLENIA PLANÓW MIEJSCOWYCH DO CYFROWEGO MODELOWANIA MIAST. DZIESIĘĆ LAT... Katarzyna Goch, Sebastian Maciulewski

\section{Bibliografia}

Goch K., Cholewiński J., Jedut A., Kunert Z., Rodak P., Osińska-Skotak K., 2017, Analysis of air flow performance in Warsaw in years 2002-2016, "AESOP Annual Congress", 11-14.07., Lizbona.

Grela J., 2017, Farma dla Aniołów, „Przegląd Piaseczyński”, 5, 157, s. 2-3.

Szulczewska B., 2016, Potencjał do kształtowania Zielonej Infrastruktury Warszawy, badanie Katedry Architektury Krajobrazu SGGW na zlecenie Urzędu m.st. Warszawy.

RPO, 2017, Znamy laureatów II edycji Złotej Księgi Dobrych Praktyk na Rzecz Społecznego Uczestnictwa Osób Starszych [online], Rzecznik Praw Obywatelskich RP, https://www.rpo. gov.pl/pl/content/znamy-laureatow-ii-edycji-zlotej-ksiegi-dobrych-raktyk [dostęp dnia: 28.09.2017]. 


\section{From plotting local spatial development plans to digital city modelling. Ten years of the Spatial Planning Scientific Club}

\section{ABSTRACT}

The aim of the article is to present ten years of the Spatial Planning Scientific Club's activities and to present an overview of the anniversary conference "10 Challenges of Spatial Planning" organized as part of the celebration of the jubilee. The Spatial Planning Scientific Club was established in 2007 at the Warsaw University of Technology Faculty of Geodesy and Cartography. The organization unites students and graduates of spatial planning at Warsaw University of Technology. The aim of the Club is to bring together students of spatial planning and to develop their interests, as well as to disseminate knowledge about related issues. The Club's main areas of interest are aspects of land-use planning and territorial management, local and regional sustainable development, environmental issues, socio-economic development and urban planning. Over the years, the Club has realised several projects, the scope of which covered and combined urbanism, environmental aspects and geographical information systems' applications. In 2008-2016 the Spatial Planning Scientific Club was a beneficiary of 8 rector's grants and organized or co-organized many conferences and workshops.

In May 2017, during the celebration of the 10th anniversary of the Scientific Club, the "10 Challenges of Spatial Planning" conference was organized. Practitioners and theorists in the fields of urban planning end environmental management attended the event, providing lectures on demography, urban resilience, transport, housing policy, landscape and natural environment protection. Conclusions from the conference indicate a need for exchange of experience among professionals as well as between the academic world and representatives of spatial planning professions.

Katarzyna Goch - specjalizuje się w analizach transportowych w skali lokalnej; studentka Gospodarki Przestrzennej na Wydziale Geodezji i Kartografii Politechniki Warszawskiej; prezes Koła Naukowego Gospodarki Przestrzennej w kadencji 2016-2017; kontakt do autorki: Koło Naukowe Gospodarki Przestrzennej, Plac Politechniki 1, p. 405/5, 00-661 Warszawa,

e-mail:kngospodarkiprzestrzennej@gmail.com

Katarzyna Goch - specializes in transport analysis at a local scale; student of Spatial Planning at the Warsaw University of Technology Faculty of Geodesy and Cartography; 2016-2017 President of the Spatial Planning Scientific Society; Contact to the author: Spatial Planning Scientific Society, Pl. Politechniki 1, p. 405/5, 00-661 Warsaw,

e-mail:kngospodarkiprzestrzennej@gmail.com

Sebastian Maciulewski - student Gospodarki Przestrzennej na Wydziale Geodezji i Kartografii Politechniki Warszawskiej w latach 2013-2017; członek Koła Naukowego Gospodarki Przestrzennej w latach 2013-2017; kontakt do autora: e-mail: sebastianmaciulewski@gmail.com

Sebastian Maciulewski - in 2013-2017 student of Spatial Planning at the Warsaw University of Technology Faculty of Geodesy and Cartography; 2013-2017 member of the Spatial Planning Scientific Society;

contact to the author: e-mail: sebastianmaciulewski@gmail.com 